\title{
Journal of Contemporary
}

\section{European Research}

Volume 16, Issue 2 (2020)

\section{Towards a Functional Division of Labour in EU development cooperation post-2020.}

\section{Patryk Kugiel}

\section{Citation}

Kugiel, P. (2020). 'Towards a Functional Division of Labour in EU development cooperation post2020.', Journal of Contemporary European Research 16 (2): 163-181.

https://doi.org/10.30950/jcer.v16i2.1080

First published at: www.jcer.net 


\section{Abstract}

Division of labour (DoL) was recognized as a priority in EU development cooperation policy a decade ago, but has lost importance in recent years. Though the Union still promotes joint programming for better aid coordination, other EU interests took precedence. This reflects general trend of instrumentalisation of European development cooperation, which is less focused on traditional goals like poverty eradication or aid effectiveness but serves more political, security, and economic self-interests. This paper traces the evolution of the European approach to DoL and highlights the major reasons for its limited successes. It claims that among most important ones was the imprecise and inadequate description of the EU's own comparative advantage and added value. The main aim of this analysis is to propose the concept functional DoL in which the European institutions focus development assistance more on the regional level while leaving national programmes to the Member States. This would better utilise the Union's unique expertise and help in more strategic allocation of EU aid. Though such a radical shift seems improbable in the short term for reasons including vested interests and path dependency, the EU can already start refocusing on regional development-cooperation programmes. This would be in line with EU external policy goals and allow it to boost regional cooperation while competing with emerging donors like China.

\section{Keywords}

European Union, development cooperation, division of labour, joint programming, foreign aid, ODA, development assistance. 


\section{INTRODUCTION}

Adoption of the Millennium Development Goals in 2000 and the sharp increase in the volume of Official Development Assistance (ODA) led also to the proliferation of donors and fragmentation of aid, which had negative effects on its effectiveness (Acharya 2006). Better coordination of work between donors became a pressing need for the international community. One of the proposed ways for better coordination of aid efforts was 'more effective Division of Labour' (DoL) and enhanced complementarity between donors in which each one would focus on the areas where it has the most expertise and can bring added value. It was assumed that this exercise could lead to a reduction of transaction costs, ease the fragmentation of aid, avoid duplication of donor initiatives, and better distribute aid between different sectors and countries (so-called 'aid orphans' and 'aid darlings').

The European Union had its own good reasons to endorse the aid effectiveness agenda in general and DoL in particular. It was already the largest provider of development assistance and with the big enlargement of 2004, it could have contributed even further to the aid fragmentation problem (Murle 2007). One study found out that EU donors (excepting the European Commission, EC) designated between 380 and 505 countries as priority partners, while the EC alone had 144 partner countries (Carlsson, Schubert, and Robinson 2009). It was assessed that DoL could address the fragmentation of aid, ease transaction costs and burdens on beneficiary governments, and bring substantial savings for the EU calculated by different authors between 200 milion euro and 5 bilion euro per year (Carlsson, Schubert, and Robinson 2009; Bigsten, Platteau, and Tengstam 2011; Anderson 2011; Prizzon and Greenhill 2012). Therefore for a few years, DoL became a hotly debated priority in the EU, with a number of documents, declarations, and initiatives adopted. With a decade passing since the EU committed itself to DoL, it is a good time to ask how successful this process has been and what is its current status?

Though aid fragmentation is a less-debated problem today, it is not less important, with more emerging donors, new aid modalities, and a need to further increase assistance to developing countries to achieve the Sustainable Development Goals (Klingebiel, Mahn and Negre 2016). What lessons can we draw from the EU experience with DoL in the past and what can be done to better utilise the expertise of European donors?

There is already quite considerable literature on coordination and aid effectiveness in EU development policy (Aldassoro, Nunenkamp and Thiele 2010, Nunenkamp, Ohler and Thiele 2013, Carbone 2013, 2015, 2017; Olivie and Perez 2015, Delputte and Soderbaum 2012, Delputte and Orbie 2014, Furness and Vollmer 2013, Galeazzi, Helly, and Krätke 2013, Helly et al. 2015, Saltnes 2019, Kruger and Steingass 2019). However, much less has been written specifically about DoL (Murle 2007, Shultz 2007, Roeske 2007, Hartman 2011) and the role played by the European Commission (EC) within this framework. Though some scholars took an interest in problems and successes of EC in coordinating works of member states (Carbone 2007, 2017, Orbie 2012), EC's own specialisation and added value in terms of DoL have escaped closer scrutiny.

This paper aims to fill these gaps and focuses on relations between EU institutions and the Member States in reducing aid fragmentation and examine accuracy of EC comparative advantage in DoL. It suggests that one possible way to make progress in this area is the adoption of a more functional approach to DoL in which the EC redirects its aid to the regional level while the Member States focus more on national programmes. The article contributes also to the nascent literature on 'politicization' of EU aid by looking at political interests behind evolution of EU approach to division of labour. 
The paper is structured as follows. The first part introduces a theoretical framework for further analysis and asks whether we can better understand EU approach to DoL in the context of the 'politicisation' of aid. The second part traces the evolution of the EU's approach to the coordination of aid from DoL to joint programming (JP), and assesses the progress achieved so far in this area, outlining major obstacles to that goals. Then, the paper turns to an analysis of the less studied role of the EC in DoL. The fourth part presents a concept of the functional DoL, together with an analysis of the main challenges and benefits for the EU. Concluding thoughts are given in the final part.

\section{HOW POLITICAL IS AID?}

There is a long and heated debate whether development cooperation is a political process serving mainly the interests of donors or just an altruistic and technical activity focused on addressing the socio-economic needs of countries and people in need (Carothers and De Gramont, 2013). In general, the scholarship on the foreign aid as phenomenon serving interests of donors, is surprisingly underdeveloped. As observed in the recent volume on this very subject 'the political grounds for giving aid are assumed, rather than explored' and as a result 'the study of the domestic politics of aid remains in an initial stage' (Olivie, Perez, 2019:1). Though there are some attempts to conceptualise this better in recent years (Woods 2005, Pankaj 2005, Lancaster 2007, van der Veen 2011, Lundsgaarde, 2012) this area needs to be better understood. Politicization of aid is understood here as instrumentalisation of aid to domestic foreign policy interests of donors rather than partner countries' needs. It is much broader concept than better known 'securitisation of aid' (Duffield 2007, Brown and Gravingholt 2016), as it can include different (not only security) interests of donors - commercial, political, migration control, soft power, etc. - in design and realisation of development cooperation.

The EU has long promoted itself as a unique altruistic donor that treats aid as an independent area of external relations focused more on the needs of developing countries than its own interests. The Maastricht Treaty (art. 130u) named as the main objectives of development cooperation traditional development goals (sustainable economic development, integration with the world economy, and a campaign against poverty). Also, the Lisbon Treaty held 'eradication of poverty' in developing countries as the main rationale for European development cooperation. Though EU aid has always been conditional and instrumental in promoting European values, this was presented in the prism of improving the effectiveness of aid and creating conditions in partner countries conducive to growth and prosperity. Though the political motivation for development cooperation of many EU member states were well acknowledged (Carbone 2007) much less has been said about similar rational for aid at Community level.

Already in the 2000s there were some voices showing EU development cooperation as driven by self-interest (Mold 2007, Holden 2009). There is a growing amount of evidence that in the post-2009 financial crisis period and under the new framework of the Lisbon Treaty, European aid has become even more closely integrated with EU foreign policy and subordinated to its larger goals. With the establishment of the European External Action Service, strengthening of Common Foreign and Security Policy under the new post of High Representative of the Union for Foreign Affairs and Security Policy and with the development of a comprehensive approach to external relations, ODA has been increasingly regarded as one of many tools to secure EU political, security, and economic interests. 
From the start of the Arab Spring in 2011 to the aftermath of the refugee crisis in 2015, the EC has been discovering the utility of aid in addressing the main challenges and solving problems that the EU faces outside its borders. The EU Global Strategy of 2016 openly said that 'development policy also needs to become more flexible and aligned with our strategic priorities' and promised to make external polices - including development - 'migrationsensitive' (EU HR/VP 2016:11, 50). Though the New European Development Consensus of 2017 upholds the 'eradication of poverty' and achievement of the Sustainable Development Goals as the primary declared goals of EU development policy, art 41, for instance, linked development cooperation clearly with EU migration aims.

Therefore, many experts, researchers, and NGOs point to a growing politicisation of EU aid, whether in the form of securitisation (Furness and Gänzle 2016) or broader instrumentalisation. This is most striking when it includes humanitarian aid, which should be governed by principles of neutrality, impartiality, and independence (Dany 2015). Also, development cooperation is more openly used for EU domestic objectives, as the new approach to stemming illegal migration clearly displays. European NGOs warned that this policy endangers the principle of solidarity on which aid is based and point to its instrumentalisation in favour of EU and national interests, such as security, conflict, and migration management (CONCORD 2018). It has been already observed that the tendency of several EU Member States to use aid for increased political leverages has negative impact on EU coordination and aid effectiveness agenda (Carbone 2017:545).

The question addressed in this paper is whether this trend of politicisation of aid has had an impact on the European approach to DoL, or, to put it differently, whether the concept of politicisation of aid can help us explain the changes in attitude to DoL and the limited success it has had thus far in improving the effectiveness of EU development assistance. Is better coordination in this field first and foremost an approach that will help the EU make its aid more effective, to better target the needs of partner countries and use the specific expertise of EU donors? Or, is it rather a mean to make the EU a more strategic actor and aid, a more useful tool in its external relations? And how can this shape the approach to DoL in the future?

\section{EVOLUTION OF THE EU APROACH TO DOL}

The EU understands DoL as sharing out the work in the development field in such a way as to avoid overlap and ensure complementarity between development partners. This also allows each partner to specialise in what it does best (area of comparative advantage) as opposed to spreading support thinly over many sectors and issues. DoL has the potential to lead to fewer and larger initiatives, delivering economies of scale and reducing administrative costs (European Commission 2018).

Division of labour has been important initiative to better coordinate the development cooperation between member states and member states and the Commission. This was necessary as development is one of shared competences according to the Maastricht Treaty (1993) and Lisbon Treaty (2009). Though first attempts at better division of labour in this field were made already in the 1990s the first decade of the new millennium brought major documents and guidelines streamlining DoL in EU development cooperation with the 'EU Code of Conduct on Complementarity and Division of Labour adopted by the Council in May 2007 as a most clear evidence of high importance of this approach. This 'voluntary and flexible' policy document (European Commission 2007), encouraged better complementarity of donors at three levels: in-country, cross-country, and cross-sector. Most important, the Code of Conduct $(\mathrm{CoC})$ proposed a set of 11 guiding principles, 
including a focus on a maximum of three sectors per partner country, and 3-5 active donors per sector, a limited number of priority countries, and addressing the problem of 'aid orphans'.

To turn words into deeds, in early 2008, the EU launched the Fast Track Initiative on Division of Labour (FTI DoL) to support a selected group of partner countries in the process of implementing in-country DoL and supported the process in several documents (DG DEV 2009, EU 2009, EU 2010) and published in June 2009 the 'EU Toolkit for the implementation of complementarity and division of labour in development policy', a practical guide explaining the main concepts, tools, and mechanisms suggested by the EC.

Though the official evaluation reports of implementation of DoL showed some progress (for instance FTI included more countries and many European donors reduced the numbers of priority sectors and countries and improved information sharing (FTI 2008, FTI 2009, FTI 2011), there was a rather modest impact of DoL on the aid-effectiveness agenda (OECD 2011, Nogaj 2013). The early OECD study observed that both in-country aid fragmentation and in-country donor proliferation have actually increased considerably, not decreased from 2005 to 2009 (OECD 2011b:2). As a result despite the EU efforts, it was concluded that 'EU donors have contributed to the increase in sectoral fragmentation in the same way as other donors' (OECD 2011b:3, CONCORD 2012:11).

Some authors argued that the reduction in sectors and priority partners was not driven by the aid-effectiveness agenda but the national interests of donors or other external circumstances (i.e. a change in government in a given country) (Aldasoro et al. 2010, Delputte et al. 2012). In general there was no 'any direct contribution of DoL processes to development outcomes' (OECD 2011a:12). There were also no compelling proofs for increased aid specialization after the Paris Declaration (Nunnenkamp et al. 2013, Nunnenkamp et al. 2015), or better synchronisation of programming cycles of different donors on the ground (O'Riordan and Benfield and de Witte 2011) or the progress in crosscountry fragmentation, which 'remained a problem' (OECD 2011c, OECD 2011d). These led some scholars to conclude that 'EU donors did not implement the guiding principles they set for themselves in the EU CoC DoL in 2007' (Burcky 2011:29).

Joint programming as new priority in aid coordination

Facing major problems in implementing DoL the Commission turned its focus to another element of aid coordination- joint programming (JP). Originally JP was seen 'as a tool to advance division of labour' (European Commission 2007: 3). Replacing the broader goal of division of labour by one of its instruments points to scaling down the level of EU ambition in coordination of aid. JP does not require EU donors to exit from certain sectors or countries, focus on one's comparative advantage nor to work towards cross-country division of labour. It can be seen as a more pragmatic way to improve coordination and harmonisation of aid.

JP aims at better planning and more coordination at country level. It means simply the joint planning of development cooperation by EU donors working in a partner country. In the following years, 'JP has emerged 'as a norm' in EU external relations, so as to promote donor coordination as well as to 'make Europe happen on the ground' (Carbone 2017: 532).

Since 2011 division of labour has been hardly present in EU documents which gave more emphasis on JP. The FTI DoL has been discontinued and monitoring of DoL in annual reports abandoned. The Union, in its common position for the Fourth High Level Forum on Aid Effectiveness in Busan in December 2011, did not mention DoL at all but committed itself 
to using it as one of five goals to 'implement joint programming at the country level to reduce aid fragmentation and promote harmonisation' (EU 2011). Similarly, also the new EU development policy, Agenda for Change, accepted by the Council in May 2012 has put emphasis on joint programming of EU and Member State aid as the way to 'reduce fragmentation and increase its impact proportionally to commitment levels'. It encouraged also other mechanisms to improve coordination, such as budget support (under a 'single EU contract'), EU trust funds, and delegated cooperation (EU 2012). In the new development cooperation strategy, the Commission observed that in the post-Lisbon Treaty framework, development policy is firmly anchored within EU external action and 'the EU and its Member States must speak and act as one to achieve better results and to improve the EU's visibility' (European Commission 2011).

In May 2016, Council adopted special conclusions to step up joint programming. It said it 'should be promoted and strengthened while being kept voluntary, flexible, inclusive, and tailored to the country context, and allow for the replacement of EU and Member States' programming documents with EU Joint Programming documents' (EU 2016). The preference for joint programming over DoL was evident also in recent strategic documents on external relations and development policy: 'EU Global Strategy' of 2016 and 'New European Consensus on Development' adopted in June 2017. The Commission and most Member States appreciate and support joint programming as long as it remains a voluntary and flexible instrument. In June 2018, the Commission published the 'Guidance Pack on Joint Programming', which replaced the first such material from April 2015 and which explains in practical terms all the issues, the mechanisms linked to joint programming, and some examples and case studies from the field. The Commission also offers capacitybuilding to the Member States through workshops, seminars, training, etc. to secure broader participation and support for the exercise. The commitment to joint programming means it will be continued and further promoted in the next multiannual financial framework (MFF) for after 2020.

Yet, despite new approach to aid coordination joint programming faced the same challenges as division of labour before. Though, the evaluation reports recognised "good progress' in strengthening joint programming and 'reducing fragmentation of development assistance' (DG DEV 2014), reduction of partner countries and an increasing number of donors engaged in different levels of joint programming (AECOM 2016), the impact on aid effectiveness was marginal. The exercise has not entered the stage of joint implementation in any single country. But as was observed in one study, 'without joint Member State-EU financing and implementation, [joint programming] is little more than a paper tiger' (Furness and Vollmer 2013).

It became clear, that joint programming has delivered thus far more positive results to the EU family rather than benefiting the partner countries or contributing to aid effectiveness. The most comprehensive evaluation of joint programming thus far published in 2017 found out the joint programming process 'very valuable for the EU and Member States' and a 'worthwhile' exercise (ADE 2017: III). It allowed for closer interaction and a better understanding of each donor's form of cooperation and also 'helped to make EU and Member States aid more harmonised, working towards commonly agreed objectives and adopting commonly agreed strategic approaches'. In addition, other benefits included improved visibility of participating donors - both as a group-the EU and the Member States-and individually. The study concluded that: 'The ambitions of joint programming in terms of aid effectiveness (reduced aid fragmentation, increased transparency and predictability, reduced transaction costs) have thus not as yet been realised' (ADE 2017: 56). 
Also, the most recent DAC OECD peer review acknowledged some benefits of joint programming exercises (they 'potentially facilitate collaboration, a clearer DoL and greater visibility of European support'), but underlined many shortcomings and challenges in its implementation (especially from the partner countries' point of view). The review recommended the EU and Member States 'continuously expand and refine implementation of their joint programming strategy, including by reinforcing partner country ownership and strengthening results-based approaches' (OECD 2018: 22), which is a veiled critique of its current status.

\section{Politicisation of aid and Division of Labour/Joint Programming}

Why DoL/JP has brought limited progress in terms of aid effectiveness agenda? Researchers point at numerous reasons - technical, administrative, institutional, financial, and political, applicable at different levels of development cooperation-in partner countries, EU Member States, and the Community. The European approach was also influenced by external developments and processes in areas of political, economic and development cooperation like, the 'war on terror', global financial crisis of 2008, the Arab Spring in 2011, 'the refuge crisis' of 2015, the post-Busan beyond-aid approach to development cooperation, new Sustainable Development Goals, Paris Climate deal or emergence of new donors - all influenced the EU to look at its development policy in a more pragmatic and realist perspective (see Graph 1). For some scholars, these changes meant that many donors became less interested in the global effectiveness agenda and aid effectiveness principle (Keijzer 2013, 10; Mawdsley, Savage, and Kim 2014).

Graph 1. Evolution of European approach to DoL between 2000 and 2018 in the global and regional context.

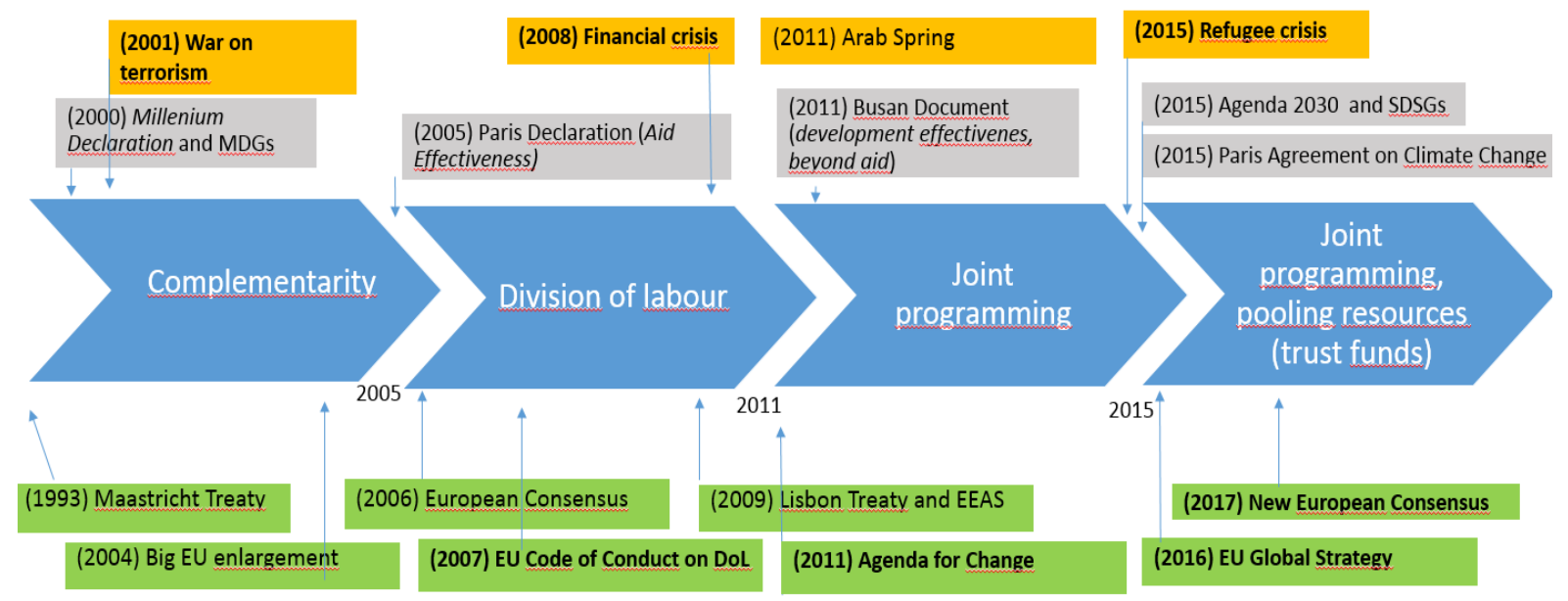

It seems however, that this phenomenon can be best explained by the trend of 'politicisation' or instrumentalisation of aid both at Member States' and Community levels. At national level, it was observed early on that lack of political will, competition between member states for the relative impact of aid, or due to visibility and foreign policy concerns, self-interests of donors, desire for bilateral control over aid, and role domestic constituencies posed major risk of failures for any coordination efforts (Roeske 2007, Schulz 2007, Hartman 2011, Annen and Moers 2012, O'Riordan and Benfield and de Witte 2011: 9). Bigsten and Tengstam (2012) claimed that even if better coordination would help reduce the costs of aid substantially, the decisions of the countries rely on their political interests. It was observed that that many donors are still acting individually and 
unilaterally when making decisions regarding the selection of partner countries and thematic areas (DG DEV 2014). For some Member States, the mechanism was seen as still too complicated and put into question the visibility of their bilateral programme (Galeazzi, Helly, and Krätke 2013). Political factors behind limited success of DoL were found in number of case studies from Morocco (Olivie, Perez and Dominguez 2013; Olivie and Perez 2015), Tanzania (Delputte and Orbie 2014), South Sudan (Furness and Vollmer 2013) or Sub-Saharan Africa (Carbone 2013).

The limited enthusiasm for DoL also reflects the weak or shallow Europeanisation of development cooperation policies of not only 'new' donors (Lightfoot, 2010, Horký, 2012, Lightfoot and Szent-Ivanyi, 2014, Henriksson, 2015) but also of more established ones (Orbie and Carbone 2016, Orbie and Lightfoot 2017). Some scholars underlined the generally low level of internal EU coordination, also because of differences in traditions in development aid and the often diverging national interests of Member States (Delputte 2013).

Some recent studies point at disagreements between different Member States' on main rationale for stronger aid coordination as reasons for slow implementation of JP. Carbone (2017: 544, 545) observed that 'a disconnect between what is decided at headquarter level and what actually happens on the ground' is due to the tensions 'between those member states that have sought to emphasize the aid effectiveness aspect of the JP initiative and those that have stressed the EU's increased political leverage'. Saltness (2019:536) pointed at possible 'collision of norms' (between country ownership and donor involvement) between even like-minded donors. Others highlighted procedural (or technical) problems in translating internationally agreed principles of Joint Programming into practical actions in EU Member states as 'administrative incompatibility in national capitals slows down implementation, even for committed member states which have intensely promoted JP in Brussels' (Kruger and Steingass 2019:439).

It confirms earlier studies that show that EU members protect their national prerogatives in development cooperation (Carbone, 2007) and substantial differences between the Member States can (and should) continue to coexist (Carbone, 2013, Delputte and Orbie, 2014). As development cooperation is seen by most states as an instrument of external relations with other countries, they do not want to reduce the visibility and impact of their bilateral programmes. Thus one research found out that 'Member States are interested in Joint Programming when it decreases their transaction costs, does not threaten their bilateral cooperation objectives and gives them more influence' (Helly at all 2015:IX).

The process of subordination of aid to larger political and strategic goals of a donor can be observed also at the Community level. As stated more openly in recent EU strategic documents on external relations and development cooperation aid is to be an effective tool for advancing EU interests and part of its comprehensive approach to external challenges. Some major internal changes and shocks, like the austerity measures or creation of EEAS in post-Lisbon Treaty context made the EU to pay more attention to its own interests than international standards. DoL and JP is being regarded today to serve more the EU strategic aims - to make it more visible, unified and influential international actor.

As the EU is not giving up on its efforts at better coordination of aid, it seems evident that the nature and purpose of DoL has changed considerably, and in line with general trends in EU development cooperation policy. The evolution of the European approach to aid coordination can be seen as transforming from complementarity in early 2000 s to division or labour since 2005 to joint programming in 2011 and pooling resources recently. And as it was driven by aid effectiveness agenda originally it is now more entangled into EU strategic considerations. 


\section{THE MISSING ELEMENT - EU INSTITUTIONS' SPECIALISATION IN DOL}

As long as development cooperation is a shared competence between the Member States and the Community and DoL/JP is of 'voluntary and non-binding nature' (EPRS 2015) it will continue to face major problems in its implementation. If EU Member States continue to guard their sovereignty over development policies, is there anything that the EC can do to implement DoL and improve the effectiveness of aid? The EC plays a dual role-it acts as 'coordinator, convener and policymaker' of European aid and at the same time, it is itself a significant donor. While the first role was crucial in driving DoL, the latter has escaped deeper analysis in this context.

The EC is one of the biggest donors in the world. In 2017, its net ODA stood at over USD 16.5 billion, making it the third biggest donor within the EU, and fourth globally (behind the US, Germany and UK) (OECD 2018). EU institutions are responsible for almost onefifth of total EU aid (16.5 per cent in 2017). Therefore, one can assume that deeper specialisation of EC aid and greater focus (geographic and sectoral) would make a great difference in a better DoL.

With a high concentration of aid, the EC has not been seen, however, as an important part of the aid-fragmentation problem. It was working hard to implement principles on aid effectiveness and focus its aid. As a recent study revealed, in line with the concentration principle and DoL, the EU country programmes have been focusing on a maximum of three sectors per country since 2014 (OECD 2018: 19). Also, a considerable part of the EC aid is being given through multilateral channels (24 per cent in 2017). The EC spends relatively big amounts of ODA to budget support, which helps ease aid fragmentation and is 'widely appreciated by partner countries' (OECD 2018: 19).

Yet, the EC delivers aid to dozens of countries in a number of sectors, often overlapping with the Member States. Though it has over the last decade withdrawn aid from many more-advanced countries and limited its assistance to middle-income countries, it still considers almost 100 countries to be priority partners, has dozens of National Indicative Programmes (along with several regional and thematic programmes), and a list of all beneficiaries exceeds 140 partners. As a result, there may be the impression that its aid goes everywhere and to every sector. One can wonder what comparative advantage the EC has over its Member States in providing assistance, for instance, to health or education sectors in a country in Africa. It is hard to understand what specialisation EC aid has when its support is spread thinly across dozens of countries and sectors. And, one may wonder whether the unique expertise of the EU is rightly utilised in its development policy. Though the Commission reassures that 'the EU is not simply the 28 $8^{\text {th }}$ European donor' (EC 2011), in practice, it delivers aid similarly to other bilateral donors.

This observation suggests that possibly the analysis of comparative advantage and added value of the EU in development cooperation was not very successful and the EU's specialisation is not clearly defined. Or maybe, that for some other reasons the theoretical understanding of the EU's unique role has not been translated into practice. One can see that both explanations apply and that despite numerous attempts at a more precise definition of EU specialisation, this has not been transformed into practice.

In a communication from 2000, the Commission observed that to go 'one step further' beyond coordination and to 'envisage a DoL' there is the need to identify areas 'where Community action offers added value' (EU 2000). It then named several strengths of the Community in relation to the Member States (i.e. global presence, bigger projects) and to other international financial institutions (i.e. big share of grants) and gave two criteria for better concentration of aid. Eventually, the document identified six priority fields for the 
Commission. However, the description of sectoral priorities was so broad that it allowed EU aid to go to most areas. This practice was even expanded in the following years.

The 'European Consensus on Development' of 2006 was crucial in defining the Community's role as a donor in general and its comparative advantage in particular but did little to better define the EC's role. Though the Commission vowed greater concentration on a 'strictly limited number of areas for action when Community aid is being programmed, instead of spreading efforts too thinly over too many sectors' (EU 2006: article 67), the document enlisted eight areas in which the Community brought added value and a long list of 12 priority sectors, which at the same time were considered the Commission's comparative advantage. This had in no sense restricted Community specialisation sector-wise. Geographically, aid at the Community level was to be focused on the countries most in need.

The 'Code of Conduct on Complementarity and Division of Labour' (2007) and 'EU Toolkit on Division of Labour' (2009) encouraged EU donors to focus their activities in areas of specialisation and gave 10 criteria that could define comparative advantage. Yet, they were framed so broadly that they hardly limited the scope of the EC's actions. On the contrary, due to its global presence, the EC was encouraged to play a role in most developing countries. Also, the following strategies on EU development policy-'Agenda for Change' (2011) and the 'New European Consensus on Development' (2017)-did not call for greater focus and concentration in Commission development assistance.

'Agenda for Change' prioritised support in two areas (human rights, democracy and good governance; inclusive and sustainable growth for human development) but did not exclude a presence in many more sectors. In terms of geography, it promoted a differentiation principle, which meant more aid for neighbourhood countries, less-developed countries, and fragile states (those most in need), and those that were making the most progress in reform ('more for more'). The Commission also committed to the rule of a maximum of three sectors per country. The 'New Consensus on Development' of 2017 focuses on broad priorities-the '5 Ps', people, planet, prosperity, peace, and partnership-but does not confine anyhow, priority areas for aid provided by European institutions.

To sum up, the EU strategic documents did not call for more precise thematic specialisation of the Commission and failed to better describe its comparative advantage. As EC considers aid increasingly as a tool in its external relations it tends to expand its areas of activity. It seems that EC shares the same constraints in approach to coordination of aid as Member States, which protect their control and visibility of development programmes. As a process of politicization of aid applies also to the EU, more effective coordination of aid may be more difficult in future.

\section{FUNCTIONAL DOL AND EU COMPARATIVE ADVANTAGE REVISITED}

Problems in coordination of aid prompted many to look for alternative solutions. One recent study suggested stronger 'centralisation of European development aid' and 'shifting more financing and management of development cooperation from member states to the $\mathrm{EU}^{\prime}$ as the best way to overcome persistent aid fragmentation problems. (Harendt, Heinemann, Weiss 2018:5). This seems, in the light of politicisation of aid, unacceptable to most member states. Therefore here another approach is proposed that takes into account political process in the EU.

The reluctance from the Member States in engaging in EU-led coordination suggests that the greatest potential for DoL rests with a redefinition of the role of the EC based on its 
sectoral specialisation. Most naturally, the comparative advantage of the EU, a sui generis and most successful regional organisation, lies in regional cooperation and integration (ECDPM 2016). No Member State has comparable expertise in this area like the EU. Under this functional DoL, the Commission would channel most of its aid to the regional level while the Member States would continue development cooperation at the national level. Instead of duplicating and competing on aid with the Member States in traditional sectors, the EC can focus on areas where it has know-how that no country can match.

Naturally, the EC has recognised regional cooperation and integration as its comparative advantage in most strategic documents on development cooperation. Support to other regions is, for the EC, not a novelty as regional programmes have long been part of its development offer. They get, however, a small fraction of EC aid, with the clear majority of it spent at the country level. For instance, in 2016, disbursements for regional programmes for Africa (EUR 303 million) comprised less than 10 per cent of its total aid to the continent (EUR 4,860 million)-a similar share as the regional envelope for Europe (EUR 334 million out of EUR 2,955 million). The second multiannual regional programme for Africa-Pan-African Programme (PanAf)-for 2018-2020 aimed at supporting the strategic partnership between Africa and the EU, received EUR 400 million (some EUR 135 million per year). The whole regional envelope for Asia in 2017 was planned at only EUR 113.5 million.

It is well known that most regions outside the EU suffer from limited intra-regional trade, poor cross-border infrastructure, weak regional institutions, and scarcity of funds for regional initiatives. This is a natural area for European support that could provide expertise and funding for other regional organisations, capacity-building, transboundary connectivity projects, and closer cooperation across borders.

The EC could naturally continue providing budget support and other modes that do not add to then aid-proliferation problem and do not duplicate Member State actions nor put extra burdens on partner countries. The Commission could also retain horizontal programmes that are important for the EU for many different reasons and where it is seen as a more impartial and credible international organisation than the Member States, such as in election observation and the promotion of human rights and democracy. Naturally, the EU should stay active in providing humanitarian aid to react swiftly to unplanned challenges, but it should, under the new approach, withdraw gradually from aid to partner countries, provided that the Member States can fill the void.

This reform would mean a historic shift in the way Community aid is delivered and it would transform the nature of the EC as a development actor. Naturally, such a revolutionary change faces a number of political, technical, and legal challenges and can be resisted by many constituencies with vested interests in the status quo (such as DG DEVCO, DG NEAR, NGOs, and the private sector, partner countries). Most important, the European Commission may fear it would lose a crucial tool, its main leverage, and an important dimension of cooperation with many developing countries in times when it more openly regards aid as an instrument of its foreign policy.

The idea of functional DoL in the EU aid conforms with the trend of politicisation of aid. First, it takes into account the fact that the opposition from member states to closer coordination and integration of aid will continue. Second it suggests that the EC as more 'political' actor can use aid in a more strategic way. In fact, the EU would uphold development cooperation as a tool in its external relations, only directing it at a different level and give the Union a bigger role at the regional level. Refocusing EC ODA to the regional level would clearly increase the effect of scale in supporting bigger projects and help other regions address major challenges and bottlenecks in regional cooperation and 
growth. This would make the EU the most important donor in this area and an influential force for regionalism and multilateralism.

In fact, one of five priorities for European foreign policy as per the 'European Union Global Strategy 2016' was support for 'regional cooperative orders'. Yet, it has not created separate and substantial funds to achieve this goal. In addition, the focus on the bigger picture would help the implementation of the EU strategy on 'Connecting Europe and Asia' of 2018, which aims to promote high standards in infrastructure investments.

By redirecting aid to the regional level, the EC would avoid overlap and duplication of efforts with the Member States, ease the fragmentation of aid and implement clear DoL. Such a change would also free resources at the EC (both in headquarters and in the field) that can be employed for better management and coordination of European donor assistance. This would secure better coherence and greater impact.

Though the coincidence of the negotiations of the next EU financial perspective (20212027) and post-Cotonou agreement with ACP countries, as well as Brexit had offered the best opportunity to fundamentally remodel EC development cooperation policy, this chance has passed already. The EC proposal for the new MFF brought important changes in the number and composition of development instruments, though the general philosophy of EC aid remains the same.

Yet, one can still introduce more gradual changes to refocus EC aid to the regional level. First, it can increase the envelopes for regions in the next MFF, thus giving the EU more chance to shape regional cooperation and integration. Second, it can strengthen and expand the mandate of the European Investment Bank (EIB), which now accounts for some 27 per cent of EC ODA (OECD 2018), to focus on connectivity projects with a regional dimension in all parts of the world. One can enhance regional investment facilities post2020 for different regions to encourage more European businesses to help develop infrastructure in developing countries or strengthen further the External Investment Plan to use innovative financial instruments, such as blending, in most regions of the world. This would be especially important in the context of expanding on an alternative option for many developing countries to the Chinese Belt and Road Initiative. Third, it can still consider establishing an additional trust fund that can finance capacity-building and training specifically for other regional organisations and allow for more regular sharing of EU experience.

\section{CONCLUSIONS}

The above analysis shows the evolution in European coordination of aid from the more comprehensive and ambitious vision of DoL to the more political and pragmatic joint programming mechanism. This shift has been driven by many reasons, including strong resistance by EU Member States against closer coordination and Europeanisation of their development polices, which are increasingly subordinated to their foreign and domestic interests. This 'politicisation of aid' trend applies also to the Community level. This is visible in two crucial dimensions:

1) At the programming level, the EU has over the years paid increasing attention to the political constraints and interests of the Member States and to its own goals at the expense of the aid-effectiveness agenda. While DoL was at the beginning closely aligned with the Paris Declaration principles on aid effectiveness, this is clearly not the main rationale behind the joint programming exercise. With the new institutional framework post-2009, more demanding 
international context, and changes in international development cooperation, the efforts at better coordination of aid are to make the EU, as illustrated in official documents, a more coherent and strategic actor. While joint programming may lead eventually to improved EU aid effectiveness, it is not the main goal of this exercise.

2) At the implementation level, the evaluation of the progress of DoL and joint programming shows that the two mechanisms have in practice served eventually more EU interests than partner countries or the aid-effectiveness agenda. Whatever positive effects they had brought thus far were applicable to the EU in terms of better cohesion, bigger leverage, and improved visibility. Much less impact has been observed in terms of strengthened ownership or lowered transaction costs for partner countries.

This paper contributes to existing literature on EU development policy and coordination of aid in three important ways. First, it confirms that among major reasons of modest progress in DoL/JP continues to be the reluctance of the Member States to give up full control over their aid programmes. With recent trends of growing opposition to further integration and Europeanisation of different EU policies (including development cooperation, but also others like migration) and more countries regarding aid as an important part of their foreign policy toolbox, there is little realistic expectation for a much success of joint programming. Coordination and 'collective action challenge in EU development policy' (Bodenstein, Faust and Furness M. 2017) will not go away easily.

Second it adds to developing discussion on 'politicization of EU aid' by showing how domestic and strategic concerns of the EU started playing more role also in its approach to division of labour and aid effectiveness. Hence, it conforms with findings that perceive the $\mathrm{EU}$ as more self-interested donor. In other words stronger coordination of EU aid (through JP) serves now more strategic interests of the EU than aid effectiveness principle. In this sense, 'politicisation of aid' as theoretical framework of analysis proved helpful in understanding the changes in EU approach to DoL.

Thirdly, it fills the gap on literature on European Commission's role in division of labour, by questioning its selected comparative advantage and specialization. It suggests that this has been ill-defined and not based on unique competences of the EU. By expanding its focus too widely, the EC became just another donor competing with the Member States and adding to the problem of aid fragmentation. At the same time, it also had fewer resources left to focus on areas where its actions could have the most impact.

In this context the paper presents a practical and original (if not revolutionary) solution to revive the division of labour. It is based on re-evaluation of comparative advantage of the EC and Members States. Under a functional DoL, the EC would focus on assistance at the regional level while leaving national programmes to its Member States. That would allow the EC to focus on issues it knows best (regional cooperation and integration) and ease tensions with the Member States, reduce aid fragmentation, and give the EU a strategic outlook to counter new big players like China. Though such a radical shift in EU aid would face numerous serious problems and may need some time to be implemented, it is certainly high time to consider this idea carefully. This rationalisation that can bring visible progress on DoL, improve aid effectiveness, and enhance the strategic coherence of the EU at the same time. 


\section{ACKNOWLEDGEMENTS}

A first draft of this paper was discussed at the "Workshop on EU International Development Cooperation post-2020 in Birmingham, UK (8-9 November 2018), and revised version was presented at the 49th Annual UACES Conference, Lisbon, September 2019. The author would like to thank Mark Furness and Balazs Szent-Ivanyi for their relevant comments and support and two anonymous referees for their helpful feedback.

\section{AUTHOR DETAILS}

Patryk Kugiel, Analyst, Polish Institute for International Affairs, 1A Warecka Street, 00-950 Warsaw. Email:kugiel@pism.pl

\section{REFERENCES}

Acharya, A., T. Fuzzo de Lima and M. Moore (2006). 'Proliferation and Fragmentation: Transaction Costs and the Value of Aid', Journal of Development Studies, 42 (1): 1-21.

ADE (2017.) Evaluation of EU Joint Programming Process of Development Cooperation (2011-2015). Final Report Volume IMain Report. Evaluation carried out on behalf of the European Commission. Brussels: Analysis for Economic Decisions. European Commission.

AECOM (2016), Effective Development Cooperation: Has the European Union delivered?, 28 November. Brussels: AECOM. European Commission.

Aldasoro, I., P. Nunnenkamp and R. Thiele (2010). 'Less aid proliferation and more donor coordination? The wide gap between words and deeds'. Journal of International Development 22 (7): 920-940.

Anderson, E. (2011). 'Aid Fragmentation and Donor Transaction Costs', International Development UEA Working Paper, 31.

Annen, K. and L. Moers (2012). 'Donor Competition for Aid Impact, and Aid Fragmentation', IMF Working Paper, 12/204.

Bigsten, A., J.P. Platteau and S. Tengstam (2011). 'The Aid Effectiveness Agenda: The Benefits of Going Ahead'. Brussels: SOGES, European Commission.

Bodenstein, T., J. Faust and M. Furness (2017). 'European Union Development Policy: Collective Action in Times of Global Transformation and Domestic Crisis', Development Policy Review, 35(4): 441-453.

Brown, S. and J. Grävingholt (eds), (2016). The Securitization of Foreign Aid, Palgrave Macmillan.

Bürcky, U. (2011). 'Trends in In-Country Aid Fragmentation and Donor Proliferation. An Analysis of Changes in Aid Allocation Patterns between 2005 and 2009'. OECD TT DoL.

Carbone, M. (2017). 'Make Europe Happen on the Ground? Enabling and Constraining Factors for European Union Aid Coordination in Africa'. Development Policy Review, 35 (4): 531-548.

Carbone, M. (2015). 'Foreign Aid, Donor Coordination and Recipient Ownership in EU-Africa Relations'. In M. Carbone (ed.), The European Union in Africa: Incoherent Policies, Asymmetrical Partnership, Declining Relevance? Manchester, UK: Manchester University Press: 121-141.

Carbone, M. (2013). 'Between EU actorness and aid effectiveness: The logics of EU aid to sub-Saharan Africa'. International Relations, 27(3): 341-355.

Carbone, M. (2007). The European Union and International Development: The Politics of Foreign Aid. London: Routledge. 
Carlsson, B.T., Schubert, C.B. and Robinson, S. (2009). 'The Aid Effectiveness Agenda: Benefits of a European Approach'. Hemel Hempstead, UK; Brussels: HTSPE, European Commission.

Carothers, T. and D. De Gramont (2013), Development Aid Confronts Politics: The Almost Revolution. Washington, DC: Carnegie Endowment for International Peace.

CONCORD (2018). AidWatch 2018. Aid and Migration: externalisation of Europe's responsibilities'. Brussels: CONCORD.

CONCORD (2012). AidWatch Report 2012: Invest More in Global Development. Brussels: CONCORD.

Dany, Ch. (2015). 'Politicization of Humanitarian Aid in the European Union', European Foreign Affairs Review, 20(3): 419438.

Delputte, S. (2013). The European Union as an emerging coordinator in development cooperation An analysis of EU coordination in Tanzania, Zambia, Burkina Faso and Senegal, Dissertation submitted by Sarah Delputte in fulfilment of the degrees 'Doctor in Political Science' (Ghent University) and 'Doctor in Development Studies' (University of Antwerp).

Delputte, S., and J. Orbie (2014). 'The EU and Donor Coordination on the Ground: Perspectives from Tanzania and Zambia'. European Journal of Development Research 26 (5): 676-691.

Delputte, S. and F. Soderbaum (2012). 'EU Aid Coordination in Africa: Is the Commission Calling the Tune?' In S. Gänzle, S. Grimm and D. Makhan (eds) The European Union and Global Development: An 'Enlightened Superpower' in the Making?, Palgrave Macmillan: 37-56.

DG DEV (2014). 'The Busan Commitments: An Analysis of EU Progress and Performance', 11 April, Brussels: European Commission.

DG DEV (2009). EU Toolkit for the implementation of complementarity and division of labour in development policy. Brussels: European Commission.

Duffield, M. (2007). Development, Security and Unending War: Governing the World of Peoples. Cambridge, UK and Malden, MA: Polity.

ECDPM (2016). 'The EU's new approach to funding regional cooperation'. GREAT Insights Magazine 5 (4), July/August. ECDPM.

EPRS (2015). 'The challenge of coordinating European development policies Fragmentation, a disaster?' European Parliament Research Service, January.

EU (2017). 'The New European Consensus on Development: Our World, Our Dignity, Our Future'. Joint Statement by the Council and the Representatives of the Governments of the Member States Meeting within the Council, the European Parliament and the European Commission. Brussels. 8 June.

EU (2016). 'Council Conclusions on stepping up Joint Programming' Brussels, 12 May.

EU (2012). 'Council conclusions 'Increasing the Impact of EU Development Policy: an Agenda for Change'.' 3166th Foreign Affairs Council meeting. Brussels, 14 May.

EU (2011). 'EU Common Position for the Fourth High Level Forum on Aid Effectiveness (Busan, 29 November - 1 December 2011). Council conclusions.' 3124th Foreign Affairs Development Council meeting, Brussels, 14 November.

EU (2007). 'EU Code of Conduct on Complementarity and Division of Labour in Development Policy-Conclusions of the Council and of the Representatives of the Governments of the Member States meeting within the Council'. Brussels, 15 may.

EU (2006). The European Consensus on Development, Joint declaration by the Council and the representatives of the governments of the Member States meeting within the Council, the European Parliament and the Commission on the development policy of the European Union entitled 'The European Consensus' [Official Journal C 46 of 24.2.2006].

EU HR/VP (2016). 'Shared Vision, Common Action: A Stronger Europe. A Global Strategy for the EU's Foreign and Security Policy'. Brussels. 
European Commission (2018). 'Joint Programming Guidance: Supporting EU Delegations to work better together with Member States, like-minded partners and country stakeholders', Brussels, June.

European Commission (2011). 'Increasing the impact of EU Development Policy: an Agenda for Change.' 13.10.2011 $\operatorname{COM}(2011) 637$ final, Brussels.

European Commission (2007). 'EU Code of Conduct on Division of Labour in Development Policy.' COM(2007) 72, February 28. Brussels.

FTI (2011). 'Third Monitoring Report and Progress Review of the EU Fast Track Initiative on Division of Labour. Annex 5 to Commission Staff Working Document EU Accountability Report 2011 on Financing for Development Review of progress of the EU and its Member States.' 19.4.2011 SEC(2011) 502 final, Brussels.

FTI (2009). '2nd Monitoring Report of the EU Fast Track Initiative on Division of Labour. A Product of the EU-Technical Seminar on Aid Effectiveness.' 30 November.

FTI (2008). 'Monitoring Report EU Fast Track Initiative on Division of Labour and Complementarity, Monitoring of the Status Quo'. A product of the EU Technical Seminar on Division of Labour and Complementarity, November.

Furness, M. and S. Gänzle (2016). 'The European Union's Development Policy: A Balancing Act between 'A More Comprehensive Approach' and Creeping Securitization' in Brown, Stephen, Grävingholt, Jörn (Eds.), The Securitization of Foreign Aid, Palgrave Macmillan: 138-162.

Furness, M. and F. Vollmer (2013). 'EU Joint Programming: Lessons from South Sudan for EU Aid Coordination'. DIE Briefing Paper 18, Bonn: German Development Institute.

Galeazzi, G., D. Helly, and F. Krätke (2013). 'All for One or Free-For-All? Early Experiences in EU Joint Programming'. ECDPM Briefing Note No. 50, Maastricht, May.

Harendt, Ch., F. Heinemann and S. Weiss (2018). Why and How There Should be More Europe in Development Policy. Gütersloh: Bertelsmann Stiftung.

Hartmann, S. (2011). 'Political Constraints on Division of Labor in Development Policy Across Countries. A Proposal for A More Viable Coordination Procedure at the EU Level', ÖFSE Working Paper, 28.

Helly, D., G. Galeazzi, A. Parshotam, C. Gregersen, W. Kokolo, and A. Sherriff (2015). 'Stepping Up? Best Practice in Joint Programming and Prospects for EU Joint Cooperation Strategies.' ECDPM Discussion Paper 183. Maastricht: ECDPM.

Henriksson, T. P. (2015). 'Europeanization of foreign-aid policy in Central and East Europe: The role of EU, external incentives and identification in foreign-aid policy adoption in Latvia and Slovenia 1998-2010', Journal of European Integration, 37(4): 433-449.

Holden P. (2009). In Search of Structural Power: EU Aid Policy as a Global Political Instrument. Farnham: Ashgate.

Horký, O. (2012). 'The impact of the shallow Europeanisation of the 'New' member states on the EU's actorness: What coherence between foreign and development policy?' in: S. Gänzle, S. Grimm \& D. Makhan (Eds). The European Union and Global Development: An ‘Enlightened Superpower’ in the Making? Basingstoke: Palgrave Macmillan, 57-73.

Keijzer, N. (2013). 'Unfinished Agenda or Overtaken by Events? Applying Aid- and Development-Effectiveness Principles to Capacity Development Support.' DIE Discussion Paper 17/2013, Bonn: German Development Institute.

Krüger L.-T. and S. Steingass (2019). 'Policy entrepreneurs in Brussels, tied hands at home? EU member states between joint policy-making and domestic implementation in development co-operation', Journal of European Integration, 41(4): 429-445.

Lancaster, C. (2007). Foreign aid: Diplomacy, Development, Domestic Politics. Chicago: University of Chicago Press.

Lightfoot, S. and B. Szent-Iványi (2014). 'Reluctant donors? The Europeanization of international development policies in the new member states', Journal of Common Market Studies, 52(6): 1257-1272.

Lightfoot, S. (2010). 'The Europeanisation of international development policies: The case of Central and Eastern European States', Europe-Asia Studies, 62(2): 329-350. 
Lundsgaarde, E. (2012). The Domestic Politics of Foreign Aid. London: Routledge.

Mawdsley, E., L. Savage, and S.-M. Kim (2014). 'A 'Post-Aid World'? Paradigm Shift in Foreign Aid and Development Cooperation at the 2011 Busan High Level Forum.' Geographical Journal 180 (1): 27-38.

Mold, A. (ed.) (2007). EU Development Policy in a Changing World: Challenges for the 21st Century. Amsterdam: Amsterdam University Press.

Mürle, H. (2007). 'Towards a division of labour in European development co-operation: operational options'. Discussion Paper 6, Bonn: German Development Institute.

Nogaj M. (2013). 'Cost of Non-Europe in Development Policy: Increasing coordination between EU donors'. Brussels: European Added Value Unit, European Parliament.

Nunnenkamp, P., A. Sotirova and R. Thiele (2015). 'Do Aid Donors Specialize and Coordinate within Recipient Countries? The Case of Malawi'. AidData Working Paper 10. Williamsburg, VA: AidData at William \& Mary.

Nunnenkamp, P., H. Öhler and R. Thiele (2013). 'Donor coordination and specialization: Did the Paris Declaration make a difference?' Review of World Economics, 149(3): 537-563.

OECD (2018), OECD Development Co-operation Peer Reviews: European Union 2018, OECD Development Co-operation Peer Reviews, OECD Publishing, Paris, https://doi.org/10.1787/9789264309494-en.

OECD (2011a). 'Division of Labour among Donors: Progress, Results and Challenges on the Road to HLF 4, Review of the Country Studies Conducted for the Evaluation of the Paris Declaration (Phase 2)', Annex 4 to Evidence on Trends in Fragmentation and Proliferation and Implementation and Results of Division of Labour Processes Key Messages for HLF 4 and Beyond TT DoL (WP-EFF, Cluster C).

OECD (2011b). 'Evidence on Trends in Fragmentation and Proliferation and Implementation and Results of Division of Labour Processes. Key Messages for HLF 4 and Beyond TT DoL (WP-EFF, Cluster C)'.

OECD (2011c). 'Cross-Country Division of Labour Findings from Research and the International Dialogue TT DoL - April 2011', Annex 5, to Evidence on Trends in Fragmentation and Proliferation and Implementation and Results of Division of Labour Processes Key Messages for HLF 4 and Beyond TT DoL (WP-EFF, Cluster C).

OECD (2011d). 'OECD Report on Division of Labour: Addressing Cross-Country Fragmentation of Aid'. Paris: OECD. November.

Olivié, I. and A. Pérez (eds) (2019). Aid Power and Politics, London: Routledge.

Olivié I., and A. Pérez (2015). 'Why don't donor countries coordinate their aid? A case study of European donors in Morocco'. Progress in Development Studies, 16 (1): 1-13.

Olivié I., A. Perez, and R. Domínguez (2013). 'Case study: Morocco'. Annex 2 to Nogaj M. (2013). 'Cost of Non-Europe in Development Policy: Increasing coordination between EU donors'. Brussels: European Added Value Unit, European Parliament.

Orbie, J., and S. Lightfoot (2017). 'Development : shallow Europeanisation?' in A. Hadfield, I. Manners, and R. Whitman (eds), Foreign policies of EU member states : continuity and Europeanisation. Abingdon: Routledge: 201-217.

Orbie, J. and Carbone, M. (2016). 'Introduction: The Europeanisation of development policy', European Politics and Society 17(1): 1-11.

Orbie, J. (2012). 'The EU's role in development: A full-fledged development actor or eclipsed by superpower temptations?' in: S. Gänzle, S. Grimm and D. Mahkan (eds) The European Union and Global Development. An 'Enlightened Superpower' in the Making? Basingstoke: Palgrave Macmillan:, 17-36.

O'Riordan, A., A. Benfield, and E. de Witte (2011). 'Joint Multi-Annual Programming. Study on European Union Donor Capacity to Synchronise Country Programming (and joint programming) at the Country Level'. Brussels, HTSPE: European Commission.

Pankaj, A. K. (2005). 'Revisiting Foreign Aid Theories', International Studies, 42:2, 103-121. 
Prizzon, A. and R. Greenhill (2012). 'The Aid Effectiveness Agenda: The Benefits of Going Ahead. A Commentary on the Final Report', EDCPS / ODI Paper.

Roeske, K. (2007). 'The Code of Conduct for a Better Division of Labour in Development Policy. Is It a Real Milestone?', Friederich Ebert Stiftung Brussels Focus, September.

Saltnes J. D. (2019). 'Resistance to EU integration? Norm collision in the coordination of development aid', Journal of European Integration, 41:4, 525-541.

Schulz, N.S. (2007). 'Division of Labour Among European Donors: Allotting the Pie or Committing to Effectiveness'. FRIDE Development in Context, 09.

van der Veen, M. (2011). Ideas, Interests and Foreign Aid, Cambridge University Press.

Woods, N. (2005). 'The Shifting Politics of Foreign Aid', International Affairs, 81(2):393-409. 